\title{
Effect of Oak Chips Application on Phenolic Compounds of Wine Vinegars at Different Maturation Times
}

\author{
Mustafa Bayram ${ }^{1, a}$, Semra Topuz ${ }^{1, b, *}$, Cemal Kaya ${ }^{1, c}$, Rahmi Ertan Anli ${ }^{2, d}$ \\ ${ }^{1}$ Department of Food Engineering, Faculty of Engineering and Architecture, Tokat Gaziosmanpaşa University, 60150 Taşliçiftlik/Tokat, Turkey \\ ${ }^{2}$ Department of Food Engineering, Faculty of Engineering, Ankara University, 06830 Gölbaşl/Ankara, Turkey
} *Corresponding author

\section{A R T I C L E I N F O A B S T R A C T}

Research Article

This study was conducted to investigate the effects of oak chips-supplementations on phenolic compound profiles of grape vinegar samples. Total acidity, volatile acids, non-volatile acids, $\mathrm{pH}$, dry extract, ash, color, alcohol, total phenolic compound, individual phenolic compounds and aroma compounds of un supplemented control (UC) samples and oak chips-supplemented (OCS) samples were analyzed at the $0^{\text {th }}, 1^{\text {st }}$ and $3^{\text {rd }}$ months of ageing. Total phenolic compound of UC vinegar samples was measured as $1256.50 \mathrm{mg} \mathrm{GAE} / \mathrm{L}$ at the end of the $3^{\text {rd }}$ month. Total phenolic compound of OCS vinegar samples was measured as $1521.03 \mathrm{mg} \mathrm{GAE} / \mathrm{L}$ at the end of the $1^{\text {st }}$ month and as $1470.67 \mathrm{mg} \mathrm{GAE} / \mathrm{L}$ at the end of the $3^{\text {rd }}$ month. Gallic acid, catechin and vanillic acid contents of UC vinegar samples were respectively measured as $8.43 \mathrm{mg} / \mathrm{L}, 22.26 \mathrm{mg} / \mathrm{L}$ and $1.78 \mathrm{mg} / \mathrm{L}$ at the end of the $3^{\text {rd }}$ month. Gallic acid, catechin and vanillic acid contents of OCS vinegar samples were respectively measured as $19.12 \mathrm{mg} / \mathrm{L}, 17.98 \mathrm{mg} / \mathrm{L}$ and $2.58 \mathrm{mg} / \mathrm{L}$ at the end of the $3^{\text {rd }}$ month. The 3-hydroxy-2-butanone, hexadecanoic acid methyl ester, 9,12-octadecadienoic acid methyl ester and 9-octadecanoic acid methyl ester quantities increased at the end of the $3^{\text {rd }}$ month with oak chipssupplementation to ageing process. It was observed that oak chips-supplementation increased total phenolic compound and some individual phenolics of grape vinegar samples.

\begin{tabular}{l|l} 
Keywords: & $\begin{array}{l}\text { end of the } 3^{\text {rd }} \text { month. Gallic acid, catechin and vanillic acid contents of OCS vinegar samples were } \\
\text { respectively measured as } 19.12 \mathrm{mg} / \mathrm{L}, 17.98 \mathrm{mg} / \mathrm{L} \text { and } 2.58 \mathrm{mg} / \mathrm{L} \text { at the end of the } 3^{\text {rd }} \text { month. The } \\
\text { Aroma }\end{array}$ \\
Grape & 3-hydroxy-2-butanone, hexadecanoic acid methyl ester, 9,12 -octadecadienoic acid methyl ester and \\
Oak chips & 9-octadecanoic acid methyl ester quantities increased at the end of the $3^{\text {rd }}$ month with oak chips- \\
Phenolics & supplementation to ageing process. It was observed that oak chips-supplementation increased total \\
Vinegar & phenolic compound and some individual phenolics of grape vinegar samples.
\end{tabular}

Vinegar

https://orcid.org/0000-0002-8232-226X https://orcid.org/0000-0001-8354-9565 b@semra.topuz@gop.edu.tr anli@eng.ankara.edu.tr
(D) https://orcid.org/0000-0002-9122-0839 Dhtps://orcid.org/0000-0002-3320-0629

\section{Introduction}

Polyphenols with some special chemical characteristics are among the most studied phytochemicals of the plants. Phenolic compounds of toasted oak barrels and alternatives commonly used in wine and vinegar production are traditional practices used to improve certain physicochemical and sensory characteristics of beverages like wine and vinegar (Guerrero et al., 2011; Cerezo et al., 2014). Soluble oak compounds are extracted into the wine and vinegar during the ageing process and such compounds increase the intensity and complexity of the tastes and aromas (Prida and Puech, 2006). The primary changes in vinegars throughout the ageing in toasted oak barrels include water loss through the pores of the wood, increase in acetic acid concentrations, extraction of phenolic compounds from the wood and formation of aroma compounds (especially the esters) (Tesfaye et al., 2004).

Oak barrels are primarily made of two different oak species with different chemical compositions: American oak, also called white oak (Quercus alba) and French oak, also called pedunculate oak (Quercus robur) or sessile oak (Quercus petraea). Besides the botanical species, the origin of the oak also significantly influences the composition of compounds extracted into the vinegar from the oak (Prida and Puech, 2006). Oak wood is composed of $40 \%$ cellulose, $20 \%$ hemicellulose, $25 \%$ lignin, $10 \%$ ellagitannin and 5\% other compounds (lipids, sterols, volatile components, minerals) (Anl1, 1999). Phenolic compounds of oak tissue are assessed under three groups: Volatile phenols, phenolic acids - aldehydes and tannins. Tannins are also assessed under two groups of hydrolysable and non-hydrolysable ones (Zhang et al., 2015). Volatile phenols and benzoic aldehydes have great contributions to the sensory characteristics of wines. The hydrolysable tannins, like ellagitannins, play significant roles in the stabilization of pigment structures (Fujieda et al., 2008). During the barrel-ageing process, some tannins, phenolic acids and phenolic aldehydes generated through degradation of lignin and phenolic acids (vanillic, syringic, 
ferulic acid); furfural and hydroxymethylfurfural type compounds generated through the transformation of cellulose during the barrel burning all pass to final product from the barrel (Anl1, 1999). During the hydrolysis of tannins (with acid, alkaline and esters), the ones yielding gallic acid are called gallotannins and the ones yielding ellagic acid are called ellagitannins. Oak heartwood and barks mostly contain ellagitannins. The primary components are catechin (flavan-3-ols) and proanthocyanidins (flavan-3,4-diols) generated through polymerization of leucoanthocyanidins. These two groups of compounds are commonly encountered in plant tissues. They are simple phenols of plant tissues and easily extracted into the final product. Since the 4-vinylphenol and 4-ethylphenol have quite high odor thresholds, they can reach sensible levels in long duration-aged products. The primary phenolic acid compounds encountered in oak wood tissue include hydroxybenzoic acids, hydroxycinnamic acids and their aldehyde forms (Zhang et al., 2015). Oak barrels have various disadvantages such as longer ageing process, high cost of barrels, large area occupation of barrels and replacement of barrels in time (Martin and Sun, 2013). Therefore, there is a need for simpler methods and cheaper wood-borne products able to shorten the ageing process, be added to vinegar at any stages of production, be stored in small packaging and allow extraction of phenolics and aroma compounds to the final product (Cano-López et al., 2007). Oak chips may be considered as an alternative method for this purpose. In this method, oak chips are supplemented with wine or vinegar in stainless steel tanks or barrels (Cano-López et al., 2007). Chips of two different oak species (American oak: white oak-Quercus alba; French oak: pedunculate oak-Quercus petrae or sessile oak-Quercus robur) are subjected to similar processes applied in the manufacture of the barrels. Such processes include air-drying, water-cooling and heat treatments. From these two types of oak trees, oak chips are prepared at different size categories and four different toasting levels (Tesfaye et al., 2004; Bozalongo et al., 2007).

Pre-treatments applied to oak chips, chip sizes and quantities influence types and quantities of the compounds extracted into the vinegar (Tesfaye et al., 2004). Oak chips can be supplemented into different processes (fermentation, ageing, and etc) of vinegar production. This study was conducted to investigate the effects of oak chipssupplementation in the ageing stage of production on general physicochemical characteristics, total phenolics, individual phenolics and aroma compounds of grape vinegar.

\section{Material and Methods}

\section{Material}

Grape vinegar produced from Narince grapes used in this study was supplied from Özkaleli Food Co. (Zile, Tokat). Oak chips (French oak, Quercus petrae and Quercus robur) with medium + toasting level used in the ageing of vinegar were supplied from Pronektar Co. (Radoux, France). Physicochemical analyses of the experimental vinegar samples were performed at laboratories in the Department of Food Engineering,
Faculty of Engineering and Architecture, Tokat Gaziosmanpaşa University.

\section{Method}

Vinegar samples were filled into glass jars fully as not to have any space at the top and then they were supplemented with $10 \mathrm{~g} / \mathrm{L}$ oak chips. Control group and oak chips-supplemented vinegar samples were stored at dark at $22-25{ }^{\circ} \mathrm{C}$ temperatures during 3 months. Analyses were performed on vinegar samples at the $0^{\text {th }}, 1^{\text {st }}$ and $3^{\text {rd }}$ months. Grape vinegar samples were analyzed before adding oak ships $\left(0^{\text {th }}\right.$ month) and general characteristics were determined. The unsupplemented control group was depicted with UC and oak chip-supplemented samples were indicated with OCS. Productions were performed in three replications.

\section{Analyses Performed on Vinegar Samples}

Total acidity (in acetic acid equivalent, g/100 mL), nonvolatile acids (in acetic acid equivalent, $\mathrm{g} / 100 \mathrm{~mL}$ ), volatile acids (in acetic acid equivalent, $\mathrm{g} / 100 \mathrm{~mL}$ ), total dry extract (\%), ash (\%) analyses were performed in accordance with OIV (2018); $\mathrm{pH}$ and density were determined in accordance with Aktan and Y1ldırım (2011).

\section{Color Analysis}

Color parameters $\left(L^{*}, a^{*}\right.$ and $\left.b^{*}\right)$ of the vinegar samples were performed through an objective measurement method with the aid of a colorimeter (Minolta CR300) (Cemeroğlu et al., 2004).

With the instrumental color parameters of;

$L^{*}$ : (0) blackness, (50) greyness, (100) whiteness,

$a^{*}:(+)$ redness, (-) greenness,

$b^{*}:(+)$ yellowness, (-) blueness was indicated.

\section{Total Phenolic Compund Analysis}

Folin-Ciocalteau method as recommended by Singleton and Rossi (1965) was used for the determination of total phenolic content. For this purpose, $100 \mu \mathrm{L}$ sample was mixed with $900 \mu \mathrm{L}$ distilled water, $5 \mathrm{~mL} 0.2 \mathrm{~N}$ FolinCiocalteau solution and $4 \mathrm{~mL} 7.5 \%$ sodium carbonate solution. The resultant mixture was incubated at room temperature for two hours and an absorbance reading was performed against the blank in a spectrophotometer at 765 $\mathrm{nm}$. Standard curve prepared with the use of gallic acid was used to determine total phenolics of the samples as $\mathrm{mg}$ gallic acid equivalent (GAE)/L.

\section{Cation Radical Scavenging Activity $\left(\boldsymbol{A B T S}^{\bullet+}\right)$}

The spectrophotometric method developed by Re et al. (1999) was used to determine the antioxidant activity of the samples. To prepare ABTS radical stock solution, ABTS solution $(7 \mathrm{mM})$ and $\mathrm{K}_{2} \mathrm{~S}_{2} \mathrm{O}_{8}$ solution $(2.45 \mathrm{mM})$ were mixed at 1:1 ratio. ABTS radical working solution was prepared as to have an absorbance value of $0.700( \pm 0.02)$ at $734 \mathrm{~nm}$ through dilution of $1 \mathrm{~mL}$ stock solution with 55 $\mathrm{mL}$ of ethyl alcohol. About $40 \mu \mathrm{L}$ sample was taken from methanol-diluted samples $(0.5 \mathrm{mg} / \mathrm{mL})$, then supplemented with $4 \mathrm{~mL}$ ABTS radical and resultant mixture was kept at dark under room temperature for 6 minutes to initiate the reaction. Mixture absorbance was measured in a spectrophotomer at $734 \mathrm{~nm}$. The calibration curves 
generated for different concentrations of standard trolox solutions were used to get cation radical scavenging activity (mg TE/L) of the samples.

\section{Individual Phenolic Compound Analysis}

Caffeic acid, (+) catechin, gallic acid, ferulic acid, $p$ coumaric acid, quercetin, quinic acid and vanillic acid were quantitatively determined with a Liquid ChromatographyTandem Mass Spectrometry (LC-MS/MS) device. Analyses were performed in two replications.

Preparation of standards: Phenolic compound standards (caffeic acid, (+) catechin, gallic acid, ferulic acid, $p$-coumaric acid, quercetin, quinic acid and vanillic acid) were supplied from "Sigma-Aldrich" Co. Methyl alcohol (for HPLC, $\geq 99.9 \%$ ) was used for all standards to prepare stock solutions. Standards were stored at $-18^{\circ} \mathrm{C}$.

Preparation of samples: About $100 \mathrm{~mL}$ was taken from vinegar samples used in analyses and samples were filtered through $0.22 \mu \mathrm{m}$ (Millex-HV) membrane filter. Resultant filtrates were transferred to automated sampler (SIL30AC) vials of LC-MS-MS device. LC-MS/MS analysis was performed using an instrument from Shimadzu composed by a LC-30AD pump coupled to an LCMS-8050 mass spectrometer. The LC separation was carried out using a C18 reversed phase column $(2.1 \mathrm{~mm} \times 150 \mathrm{~mm}, 3$ $\mu \mathrm{m}$ particle size). The flow rate was set at $0.4 \mathrm{~mL} / \mathrm{min}$ using (A) $5 \mathrm{mM}$ ammonium acetate and (B) methanol as elution solvents. The following gradient program was used: $\mathrm{t}=0.0 \mathrm{~min}, 95 \% \mathrm{~A}, 5 \% \mathrm{~B} ; \mathrm{t}=8.0 \mathrm{~min}, 5 \% \mathrm{~A}, 95 \% \mathrm{~B}$; $\mathrm{t}=10.31 \mathrm{~min}, 95 \% \mathrm{~A}, 5 \% \mathrm{~B}$. The run time was 14 minutes.

\section{Aroma Compounds Analysis}

Aroma compounds were analysed with the aid of a Shimadzu-brand QP2010 Ultra model Gas Chromatography-Mass Spectrometry (GC-MS) device in accordance with the method specified by Angioni et al. (2012). For this purpose, $5.0 \mathrm{~mL}$ vinegar sample was placed into $10 \mathrm{~mL}$ screw-cap centrifuge tubes together with $3.5 \mathrm{~g}$ anhydrous $\mathrm{MgSO}_{4}$. The mixture was stirred with a micro spatula to have a homogeneous mixture. Tubes were then centrifuged and the resultant supernatant was diluted with methanol at $1: 1(\mathrm{v} / \mathrm{v})$ ratio and filtered through 0.45 $\mu \mathrm{m}$ filters. Samples were injected into the GC-MS device. The injector and transfer line was set at $200^{\circ} \mathrm{C}$.

Temperature Gradient: 1 minute at $50^{\circ} \mathrm{C}, 3^{\circ} \mathrm{C}$ per minute gradient until $220^{\circ} \mathrm{C}$ and 13 minutes at $220^{\circ} \mathrm{C}$. Carrier gas: Helium ( $1 \mathrm{~mL} / \mathrm{min}$ flow rate). Analyses were performed in two replications.

\section{Statistical Analysis}

The statistical analysis of research results was done with the help of SPSS (version 20.0) statistical package program.

\section{Results and Discussion}

\section{Physicochemical Characteristics of Vinegar Samples}

The physicochemical characteristics of the grape vinegar samples used in this study are provided in Table 1.

The type and quantity of organic acids of the vinegars largely depend on raw materials and selected method of production. Acetic acid is the major organic acid of vinegars (Plessi, 2003). Ethyl alcohol is oxidized by
Acetobacter or Gluconobacter species and ethyl alcohol quantity is reduced through the fermentation of acetic acid. The acidity of vinegars is determined with the titration method and the method yields free mineral and organic acid (acetic acid, tartaric acid, malic acid, succinic acid and etc) quantities (Aktan and Kalkan, 2011).

In unsupplemented control (UC) samples, the volatile acid quantity was determined as $30.85 \mathrm{~g} / \mathrm{L}$ in the $0^{\text {th }}$ month. In the $3^{\text {rd }}$ month of analyses, the volatile acid quantity was measured as $27.11 \mathrm{~g} / \mathrm{L}$ in UC samples and as $26.68 \mathrm{~g} / \mathrm{L}$ in oak chips-supplemented samples (OCS). In another study, Sáiz-Abajo et al. (2006) reported that volatile acid contents of the vinegar samples ranged between 9.9-116.4 g/L.

The non-volatile acid content of UC samples was measured as $2.63 \mathrm{~g} / \mathrm{L}$ in the $0^{\text {th }}$ month. In the $3^{\text {rd }}$ month of the analyses, the non-volatile acid quantity was measured as $5.63 \mathrm{~g} / \mathrm{L}$ in UC samples and as $4.91 \mathrm{~g} / \mathrm{L}$ in OCS samples. Sáiz-Abajo et al. (2005) reported that non-volatile acid quantities of vinegar samples ranged between $0.1-1.8 \mathrm{~g} / \mathrm{L}$.

The total acidity of UC samples was measured as 33.48 $\mathrm{g} / \mathrm{L}$ in the $0^{\text {th }}$ month. In the $3^{\text {rd }}$ month of analyses, total acidity was measured as $32.74 \mathrm{~g} / \mathrm{L}$ in UC samples and as $31.59 \mathrm{~g} / \mathrm{L}$ in OCS samples. According to vinegar standards of the Turkish Standards Institute (Anonymous, 2003), "Total acidity (in free acetic acid equivalent) of vinegars produced in Turkey should not be less $40 \mathrm{~g} / \mathrm{L}$ ". According to standards of the USA, acetic acid content should be at least $4 \%$. Although bottled British vinegars generally have $5 \%$ acetic acid content, acetic acid content of $4 \%$ is recommended in British Food Standards (Adams, 1998). Sáiz-Abajo et al. (2005) indicated that total acidity of vinegar samples ranged between 10.0-119.1 g/L.

The $\mathrm{pH}$ value of $\mathrm{UC}$ samples was measured as 3.79 in the $0^{\text {th }}$ month. In the $3^{\text {rd }}$ month of analyses, $\mathrm{pH}$ value was measured as 3.69 in UC vinegar samples and as 3.78 in OCS vinegar samples. Ozturk et al. (2015) reported that $\mathrm{pH}$ values of traditional homemade vinegar samples ranged between 2.70-3.90. The ethyl alcohol quantity of all samples was below $0.5 \%(\mathrm{v} / \mathrm{v})$. The value of UC samples was $0.15 \%(\mathrm{v} / \mathrm{v})$ in the $0^{\text {th }}$ month. In the $3^{\text {rd }}$ month of analyses, alcohol content was measured as $0.12 \%(\mathrm{v} / \mathrm{v})$ in UC vinegar samples and as $0.10 \%(\mathrm{v} / \mathrm{v})$ in OCS vinegar samples. Alcohol is the most significant indicator of vinegar quality and efficiency. According to vinegar standards of Turkish Standards Institute (TS 1880 EN 13188), alcohol content should not be greater than $1.5 \%$ $(\mathrm{v} / \mathrm{v})$ in wine vinegars and $0.5 \%(\mathrm{v} / \mathrm{v})$ in the other vinegars (Anonymous, 2003).

The dry extract quantity of UC samples was measured as $42.53 \mathrm{~g} / \mathrm{L}$ in the $0^{\text {th }}$ month. In the $3^{\text {rd }}$ month of the analyses, dry extract quantity was measured as $41.28 \mathrm{~g} / \mathrm{L}$ in UC samples and as $42.28 \mathrm{~g} / \mathrm{L}$ OCS samples. There aren't any threshold values specified for dry extracts in vinegar standards of the Turkish Standards Institute (TS 1880 EN 13188) (Anonymous, 2003).

Ash represents unburnt substances of vinegars and it is composed of anionic and cationic ions (Anonymous, 2003). Ash content of UC samples were $6.47 \mathrm{~g} / \mathrm{L}$ in the $0^{\text {th }}$ month. In the $3^{\text {rd }}$ month of the analyses, ash content was measured as $6.34 \mathrm{~g} / \mathrm{L}$ in UC vinegar samples and as 6.45 g/L OCS vinegar samples. According to TS $1880 \mathrm{EN}$ 13188 vinegar standards, the ash content of the vinegars should be minimum $0.8 \mathrm{~g} / \mathrm{L}$. 
Table 1. Physicochemical characteristics of vinegar samples

\begin{tabular}{l|ccccc}
\hline \multirow{2}{*}{\multicolumn{1}{c|}{ Analyses }} & $0^{\text {th }}$ month & \multicolumn{2}{c}{$1^{\text {st }}$ month } & \multicolumn{2}{c}{$3^{\text {rd }}$ month } \\
\cline { 2 - 6 } & UC & UC & OCS & UC & OCS \\
\hline Volatile acid (g/L)* & $30.85 \pm 0.24^{a^{* *}}$ & $30.4 \pm 0.25^{\mathrm{a}}$ & $30.39 \pm 0.19^{\mathrm{a}}$ & $27.11 \pm 1.12^{\mathrm{b}}$ & $26.68 \pm 0.42^{\mathrm{b}}$ \\
Non-volatile acid (g/L)* & $2.63 \pm 0.12^{\mathrm{b}}$ & $2.58 \pm 0.09^{\mathrm{b}}$ & $2.75 \pm 0.26^{\mathrm{b}}$ & $5.63 \pm 1.69^{\mathrm{a}}$ & $4.91 \pm 0.66^{\mathrm{a}}$ \\
Total acid (g/L)* & $33.48 \pm 0.36^{\mathrm{a}}$ & $32.98 \pm 0.34^{\mathrm{a}}$ & $33.14 \pm 0.07^{\mathrm{a}}$ & $32.74 \pm 0.57^{\mathrm{a}}$ & $31.59 \pm 0.24^{\mathrm{a}}$ \\
$\mathrm{pH}$ & $3.79 \pm 0.02^{\mathrm{a}}$ & $3.69 \pm 0.02^{\mathrm{b}}$ & $3.68 \pm 0.02^{\mathrm{b}}$ & $3.69 \pm 0.05^{\mathrm{ab}}$ & $3.78 \pm 0.02 \mathrm{a}$ \\
Alcohol (\%h/h) & $0.15 \pm 0.04^{\mathrm{a}}$ & $0.15 \pm 0.06^{\mathrm{a}}$ & $0.13 \pm 0.05^{\mathrm{a}}$ & $0.12 \pm 0.03^{\mathrm{a}}$ & $0.10 \pm 0.03^{\mathrm{a}}$ \\
Density (g/cm $\left.{ }^{3}\right)$ & $1.03 \pm 0.00^{\mathrm{a}}$ & $1.02 \pm 0.00 \mathrm{a}$ & $1.02 \pm 0.00^{\mathrm{a}}$ & $1.03 \pm 0.00^{\mathrm{a}}$ & $1.03 \pm 0.00^{\mathrm{a}}$ \\
Dry extract (g/L) & $42.53 \pm 0.19^{\mathrm{a}}$ & $42.48 \pm 0.32^{\mathrm{a}}$ & $42.83 \pm 0.50^{\mathrm{a}}$ & $41.28 \pm 0.28^{\mathrm{a}}$ & $42.28 \pm 0.47^{\mathrm{a}}$ \\
Ash (g/L) & $6.47 \pm 0.09^{\mathrm{a}}$ & $6.39 \pm 0.13^{\mathrm{a}}$ & $6.32 \pm 0.14^{\mathrm{a}}$ & $6.34 \pm 0.05^{\mathrm{a}}$ & $6.45 \pm 0.09^{\mathrm{a}}$ \\
$L^{*}$ & $18.13 \pm 0.03^{\mathrm{a}}$ & $18.14 \pm 0.05^{\mathrm{a}}$ & $18.18 \pm 0.13^{\mathrm{a}}$ & $18.35 \pm 0.05^{\mathrm{a}}$ & $18.42 \pm 0.24^{\mathrm{a}}$ \\
$a^{*}$ & $0.72 \pm 0.07^{\mathrm{b}}$ & $0.81 \pm 0.14^{\mathrm{ab}}$ & $1.06 \pm 0.25^{\mathrm{a}}$ & $1.33 \pm 0.07^{\mathrm{a}}$ & $1.41 \pm 0.47^{\mathrm{a}}$ \\
$b^{*}$ & $2.07 \pm 0.06^{\mathrm{a}}$ & $1.91 \pm 0.07^{\mathrm{a}}$ & $2.14 \pm 0.17^{\mathrm{a}}$ & $2.24 \pm 0.18^{\mathrm{a}}$ & $2.41 \pm 0.45^{\mathrm{a}}$ \\
\hline
\end{tabular}

* Acetic acid equivalent, ** Small letters in same line show difference between vinegar samples $(\mathrm{P}<0.05)$

The density of UC samples was measured as $1.03 \mathrm{~g} / \mathrm{cm}^{3}$ in the $0^{\text {th }}$ month. In the $3^{\text {rd }}$ month of the analyses, density values did not change, thus both UC vinegar samples and OCS vinegar samples had the value of $1.03 \mathrm{~g} / \mathrm{cm}^{3}$. Plessi, (2003) reported the density of wine vinegars as between $1.013-1.020 \mathrm{~g} / \mathrm{cm}^{3}$. Plessi, (2003) indicated density values of balsamic vinegars as between $1.042-1.361 \mathrm{~g} / \mathrm{cm}^{3}$.

In the $0^{\text {th }}$ month of analyses, $L^{*}$ value of UC vinegar samples was measured as $18.13, a^{*}$ value was measured as 0.72 and $b^{*}$ value was measured as 2.07 . In the $3^{\text {rd }}$ month of analyses, $L^{*}, a^{*}$ and $b^{*}$ values of UC vinegar samples were respectively measured as $18.35,1.33$ and 2.24 . The $L^{*}$ value of OCS vinegar samples was measured as 18.42 , $a^{*}$ value as 1.41 and $b^{*}$ value as 2.41 . The differences in $L^{*}, a^{*}$ and $b^{*}$ values of UC and OCS vinegar samples in different months were not found to be significant ( $p>0.05$ ). In a study, the color values of two different grape vinegars were determined as $L^{*}(10.4,7.31), a^{*}(7.31,12.79) b^{*}$ (17.82, 12.54) (Bayram et al., 2018). In another study, twenty-five vinegar samples were collected from different cities in Turkey. It was determined that the $L^{*}, a^{*}, b^{*}$ values of vinegars (apple, artichoke, grape, hawthorn, lemon, pomegranate, sour cherry, apple-lemon) ranged between $(0.28$ and 20.15$),(-0.54$ to 14.88$)$ and $(0.43$ to 14.11), respectively. The difference in color values may vary according to the fruit species (Ozturk et al., 2015).

Total Phenolic Compound and Cation Radical Scavenging Activity $\left(\right.$ ABTS $\left.^{\bullet+}\right)$ of Vinegar Samples

Total phenolic compound of vinegar samples is provided in Table 2. A large portion (about $80 \%$ ) of vinegars is constituted by water and the rest $(20 \%)$ is constituted by organic acids, alcohols, polyphenols and amino acids (Casale et al., 2006). Fruits, vegetables and foodstuffs produced from them play significant roles in human health because of their rich phenolic contents. Since phenolic compounds constituted a criterion for separation of natural and artificial vinegars, they play a significant role in the identification of vinegar composition. Vinegar phenolics are influenced by raw material and method of production (Tesfaye et al., 2004).

Total phenolic compound quantity of UC vinegar samples was measured as $1234.54 \mathrm{mg} \mathrm{GAE} / \mathrm{L}$ in the $0^{\text {th }}$ month. In the $3^{\text {rd }}$ month of analyses, total phenolics were measured as $1256.50 \mathrm{mg}$ GAE/L in UC vinegar samples and as $1470.67 \mathrm{mg}$ GAE/L in OCS vinegar samples. Present findings revealed that oak chips-supplementation increased $(23.25 \%)$ total phenolic compound of vinegar samples. Differences in total phenolics of the UC vinegar samples and OCS vinegar samples at the end of the $1^{\text {st }}$ and $3^{\text {rd }}$ months were found to be significant $(\mathrm{P}<0.05)$. However, the differences in total phenolics of OCS vinegar samples at the end of the $1^{\text {st }}$ and $3^{\text {rd }}$ months were not found to be significant $(\mathrm{P}>0.05)$.

Cation radical scavenging activity of the vinegar samples are provided in Table 2 . ABTS cation radical scavenging activity of UC vinegar samples were measured as 2220.00 $\mathrm{mg} \mathrm{TE} / \mathrm{L}$ in the $0^{\text {th }}$ month. In the $3^{\text {rd }}$ month of analyses, ABTS cation radical scavenging activity was measured as $2088.75 \mathrm{mg}$ TE/L in UC vinegar samples and as $2595.00 \mathrm{mg}$ TE/L in OCS vinegar samples. Present findings revealed that oak chips-supplementation increased ABTS cation radical scavenging activity in the $1^{\text {st }}$ month respectively by 19.98 and $15.31 \%$ as compared to the $0^{\text {th }}$ month and UC samples of the $1^{\text {st }}$ month; increased again ABTS cation radical scavenging activity in the $3^{\text {rd }}$ month respectively by 16.89 and $24.23 \%$ as compared to the $0^{\text {th }}$ month and UC samples of the $3^{\text {rd }}$ month. The differences in ABTS cation radical scavenging activity of UC and OCS vinegar samples at the end of the $1^{\text {st }}$ and $3^{\text {rd }}$ months were found to be significant $(\mathrm{P}<0.05)$. However, the differences in ABTS cation radical scavenging activity of OCS vinegar samples at the end of the $1^{\text {st }}$ and $3^{\text {rd }}$ months were not found to be significant $(\mathrm{P}>0.05)$.

In a study, the antioxidant activity of 18 vinegar samples (apple, apricot, artichoke, balsamic, blackberry, blueberry, date, gilaburu, grape, hawtorn, mulberry, lemon, pomegranate, rice, rosehip) were investigated by ABTS method. It was determined that the antioxidant activity of vinegars ranged between $326-3730 \mathrm{mg}$ TE/L. Antioxidant activity of two different grape vinegars were determined as $560 \mathrm{mg}$ TE/L and $1000 \mathrm{mg}$ TE/L (Bakir et al., 2017). In another study, antioxidant activity (ABTS method) of grape vinegar was determined as $441 \mathrm{mg}$ TE/L (Sengun et al., 2019).

Plant phenolic compounds are used as natural antioxidants because of their high antioxidant activities (Bouaziz and Sayadi, 2005). Potential antioxidant activity of phenolic compounds comes from hydroxyl groups (especially from 1,2-dihydroxybenzene). Hydroxyl groups donate their hydrogens and neutralize free radicals to prevent oxidation (Hassen et al., 2015). Antioxidant capacity is also derived from chelating ability with metal ions constituting free radicals (Croft, 1998). Phenolics are also able to directly or indirectly interfere with cytochrome P450 
isoforms, lypoxygenase-like enzymes catalyzing radical production (Yang et al., 2001). Increasing ABTS cation radical scavenging activity of OCS samples may be attributed to increasing total phenolic compound and some individual phenolics. Singh et al. (2018) determined ABTS cation radical scavenging activity of twelve different phenolic acids (gallic, caffeic, syringic, t-chlorogenic, ferulic, gentisic (sodium salt), colic, shikimic, cinnamic, vanillic, $p$-coumaric and quinic acids) and indicated that gentisic acid had the greatest ABTS cation radical scavenging activity and it was followed by $p$-coumaric acid and gallic acid. Present increasing ABTS cation radical scavenging activity with increasing gallic and vanillic acid quantities comply with the findings of Singh et al. (2018). Synergic effects of these phytochemicals may also increase antioxidant activity and thus may have significant health benefits.

Individual Phenolic Compounds of Vinegar Samples

Individual phenolic compound of the present vinegar samples is provided in Table 3. Individual phenolic quantities of the vinegar samples are provided in Table 4.

The quinic acid content of UC vinegar samples were measured as $72.78 \mathrm{mg} / \mathrm{L}$ in the $0^{\text {th }}$ month, as $66.08 \mathrm{mg} / \mathrm{L}$ at the end of the $1^{\text {st }}$ month and as $68.14 \mathrm{mg} / \mathrm{L}$ at the end of the $3^{\text {rd }}$ month. Quinic acid quantity of OCS vinegar samples were measured as $66.84 \mathrm{mg} / \mathrm{L}$ in the $1^{\text {st }}$ month and as 69.23 $\mathrm{mg} / \mathrm{L}$ in the $3^{\text {rd }}$ month.

Tesfaye et al. (2004) supplemented Sherry wine vinegars with $2 \%$ boiled and toasted mid-size oak ships and aged the resultant vinegars for 90 days. Researchers indicated that total phenolics rapidly increased during the initial 15 days of ageing and total phenolic compound did not change much throughout the rest of the ageing period.

Gallic acid content of UC vinegar samples were measured as $6.40 \mathrm{mg} / \mathrm{L}$ in the $0^{\text {th }}$ month, as $6.14 \mathrm{mg} / \mathrm{L}$ at the end of the $1^{\text {st }}$ month and as $8.43 \mathrm{mg} / \mathrm{L}$ at the end of the $3^{\text {rd }}$ month. Gallic acid content of OCS vinegar samples were measured as $9.77 \mathrm{mg} / \mathrm{L}$ in the $1^{\text {st }}$ month and as 19.12 $\mathrm{mg} / \mathrm{L}$ in the $3^{\text {rd }}$ month. The chromatogram for OCS vinegar samples is presented in Figure 1.

Catechin content of UC vinegar samples were measured as $19.03 \mathrm{mg} / \mathrm{L}$ in the $0^{\text {th }}$ month, as $19.22 \mathrm{mg} / \mathrm{L}$ in the $1^{\text {st }}$ month and as $22.26 \mathrm{mg} / \mathrm{L}$ in the $3^{\text {rd }}$ month. The catechin content of OCS vinegar samples were measured as $17.28 \mathrm{mg} / \mathrm{L}$ in the $1^{\text {st }}$ month and as $17.98 \mathrm{mg} / \mathrm{L}$ in the $3^{\text {rd }}$ month. The vanillic acid content of UC vinegar samples was measured as $1.67 \mathrm{mg} / \mathrm{L}$ in the $0^{\text {th }}$ month, as $1.70 \mathrm{mg} / \mathrm{L}$ in the $1^{\text {st }}$ month and as $1.78 \mathrm{mg} / \mathrm{L}$ in the $3^{\text {rd }}$ month. An increase was observed in vanillic acid contents of OCS vinegar samples and the values were measured as 2.18 $\mathrm{mg} / \mathrm{L}$ in the $1^{\text {st }}$ month and as $2.58 \mathrm{mg} / \mathrm{L}$ in the $3^{\text {rd }}$ month.

Table 2. Total phenolics and ABTS radical cation scavenging activity of the vinegar samples

\begin{tabular}{|c|c|c|}
\hline Months & Samples Total phenolics (mg GAE/L) & ABTS radical cation scavenging activity (mg TE/L) \\
\hline $0^{\text {th }}$ month & UC $\quad 1234.54 \pm 78.36^{b^{*}}$ & $2220.00 \pm 35.36^{\mathrm{b}}$ \\
\hline & $1271.81 \pm 11.92^{\mathrm{b}}$ & $2255.81 \pm 11.92^{\mathrm{b}}$ \\
\hline $1^{\mathrm{st}}$ month & $1521.03 \pm 50.78^{\mathrm{a}}$ & $2663.75 \pm 8.84^{\mathrm{a}}$ \\
\hline $3^{\text {rd }}$ month & $\begin{array}{c}1256.5 \pm 52.28^{\mathrm{b}} \\
1470.67 \pm 43.16 \mathrm{a}\end{array}$ & $\begin{array}{c}2088.75 \pm 8.84^{\mathrm{c}} \\
2595.00 \pm 159.1^{\mathrm{a}}\end{array}$ \\
\hline
\end{tabular}

*Small letters in same line show difference between vinegar samples $(\mathrm{P}<0.05)$

Table 3. LC-MS-MS data for individual phenolics of the vinegar samples

\begin{tabular}{l|cccc}
\hline \multicolumn{1}{c|}{ Individual Phenolics } & $\mathrm{R}^{2}$ & Retention time $(\mathrm{min})$ & $\mathrm{MS}, \mathrm{m} / \mathrm{z} \mathrm{M}$ & $\mathrm{MS} / \mathrm{MS}$ ion $\mathrm{m} / \mathrm{z}$ \\
\hline Quinic Acid & 0.9979 & 0.9 & 191.20 & $92.5,84.9$ \\
Gallic Acid & 0.9986 & 1.08 & 168.80 & $78.9,125.00$ \\
Vanillic Acid & 0.9975 & 2.11 & 166.80 & $152.10,108.0$ \\
Caffeic Acid & 0.9985 & 2.41 & 179.20 & $109.20,117.20,134.20$ \\
p-coumaric Acid & 0.9967 & 3.0 & 163.20 & $93.10,117.10,119.20$, \\
Ferulic Acid & 0.9987 & 3.50 & 193.20 & $89.20,105.20,133.10$ \\
Catechin & 0.9976 & 4.45 & 289.20 & $109.10,123.10$ \\
Quercetin & 0.9989 & 5.12 & 300.80 & $107.10,151.10$ \\
\hline
\end{tabular}

Table 4. Individual phenolic quantities of the vinegar samples

\begin{tabular}{l|ccccc}
\hline & $0^{\text {th }}$ month & $1^{\text {st }}$ month & $3^{\text {rd }}$ month \\
\hline Individual Phenolics (mg/L) & UC & UC & OCS & UC & OCS \\
Quinic Acid & $72.78 \pm 8.04^{a^{*}}$ & $66.08 \pm 1.71^{\mathrm{a}}$ & $66.84 \pm 0.66^{\mathrm{a}}$ & $68.14 \pm 0.66^{\mathrm{a}}$ & $69.23 \pm 0.32^{\mathrm{a}}$ \\
Gallic Acid & $6.40 \pm 0.13^{\mathrm{c}}$ & $6.14 \pm 1.92^{\mathrm{c}}$ & $9.77 \pm 0.65^{\mathrm{b}}$ & $8.43 \pm 0.71^{\mathrm{bc}}$ & $19.12 \pm 0.72^{\mathrm{a}}$ \\
Vanillic Acid & $1.67 \pm 0.03^{\mathrm{c}}$ & $1.70 \pm 0.05^{\mathrm{c}}$ & $2.18 \pm 0.03^{\mathrm{b}}$ & $1.78 \pm 0.006^{\mathrm{c}}$ & $2.58 \pm 0.11^{\mathrm{a}}$ \\
Caffeic Acid & $2.02 \pm 0.05^{\mathrm{a}}$ & $2.22 \pm 0.05^{\mathrm{a}}$ & $1.94 \pm 0.15^{\mathrm{a}}$ & $2.22 \pm 0.16^{\mathrm{a}}$ & $2.02 \pm 0.01^{\mathrm{a}}$ \\
p-coumaric Acid & $0.29 \pm 0.04^{\mathrm{a}}$ & $0.32 \pm 0.03^{\mathrm{a}}$ & $0.25 \pm 0.02^{\mathrm{a}}$ & $0.32 \pm 0.03^{\mathrm{a}}$ & $0.26 \pm 0.02^{\mathrm{a}}$ \\
Ferulic Acid & $0.26 \pm 0.02^{\mathrm{b}}$ & $0.25 \pm 0.001^{\mathrm{b}}$ & $0.30 \pm 0.06^{\mathrm{ab}}$ & $0.25 \pm 0.007^{\mathrm{b}}$ & $0.31 \pm 0.002^{\mathrm{a}}$ \\
Catechin & $19.03 \pm 0.29^{\mathrm{b}}$ & $19.22 \pm 1.20^{\mathrm{b}}$ & $17.28 \pm 0.09^{\mathrm{c}}$ & $22.26 \pm 0.54^{\mathrm{a}}$ & $17.98 \pm 0.48^{\mathrm{bc}}$ \\
Quercetin & $0.77 \pm 0.31^{\mathrm{a}}$ & $0.42 \pm 0.25^{\mathrm{a}}$ & $0.15 \pm 0.05^{\mathrm{a}}$ & $0.16 \pm 0.08^{\mathrm{a}}$ & $0.14 \pm 0.07^{\mathrm{a}}$ \\
\hline Total & 102.15 & 95.93 & 100.20 & 103.9 & 111.50 \\
\hline
\end{tabular}

*Small letters in same line show difference between vinegar samples $(\mathrm{P}<0.05)$ 


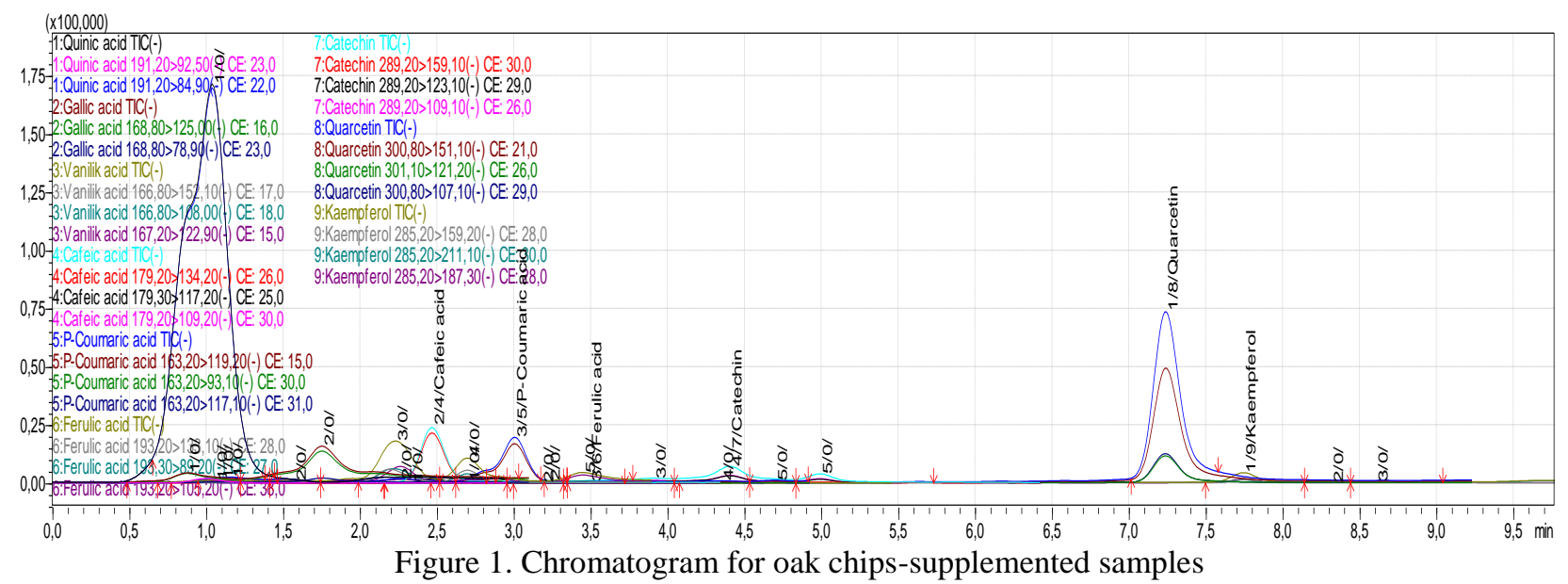

Among the individual phenolics of the vinegar samples, quinic acid had the greatest quantities in the $0^{\text {th }}, 1^{\text {st }}$ and $3^{\text {rd }}$ months. It was followed by catechin and gallic acid, respectively. Different from the other months, gallic acid had the second greatest quantity after quinic acid in the $3^{\text {rd }}$ month. In general, as compared to the $0^{\text {th }}$ month, gallic acid and vanillic acid contents increased in OCS samples. The rate of increase in gallic acid quantity was $52.65 \%$ in the $1^{\text {st }}$ month and $198.5 \%$ in the $3^{\text {rd }}$ month. The rate of increase in vanillic acid content was $30.54 \%$ in the $1^{\text {st }}$ month and $54.49 \%$ in the $3^{\text {rd }}$ month. The differences in gallic and vanillic acid contents of the UC and OCS vinegar samples at the end of the $1^{\text {st }}$ and $3^{\text {rd }}$ months were found to be significant $(\mathrm{P}<0.05)$. However, differences in quinic acid, caffeic acid, p-coumaric acid and ferulic acid contents of the UC and OCS vinegar samples at the end of the $1^{\text {st }}$ and $3^{\text {rd }}$ months were not found to be significant $(\mathrm{P}>0.05)$. As compared to UC vinegar samples, the catechin contents of OCS vinegar samples decreased at the end of the $1^{\text {st }}$ and $3^{\text {rd }}$ months. The differences in gallic acid contents of UC and OCS vinegar samples at the end of the $1^{\text {st }}$ and $3^{\text {rd }}$ months were found to be significant $(\mathrm{P}<0.05)$. The differences in vanillic acid contents of the UC and OCS vinegar samples at the end of the $1^{\text {st }}$ and $3^{\text {rd }}$ months were also found to be significant $(\mathrm{P}<0.05)$. The differences in catechin contents of the UC and OCS vinegar samples were not found to be significant at the end of the $1^{\text {st }}$ month $(\mathrm{P}>0.05)$, but found to be significant at the end of the $3^{\text {rd }}$ month $(\mathrm{P}<0.05)$.

In general, of the phenolic acids, gallic acid and vanillic acids of hydrobenzoic group of acids increased, but a significant increase was not observed in $p$-coumaric acid, caffeic acid and ferulic acids of hydrocinnamic group of acids of OCS vinegar samples. Catechin of flavan-3-ol group of flavonols decreased in OCS samples. Proanthocyanins composed of catechin and epicatechin combinations are extracted into wine vinegar during the maceration, pressing and fermentation processes (He et al., 2008). Gómez-Plaza et al. (2002) investigated the effects of different pressed grape fermentation durations $(4,5$ and 10 days) on solubility of phenol compounds and reported that the wines with longer fermentation durations had high catechin and procynadin compounds and polymeric compound quantities increased throughout the ageing process. Celulose and ellagitannins-like polymer phenols are degraded into aldehydes, furfural derivatives and lactones-like several compounds through the heat treatments applied to oak chips and these compounds then pass to the final product during the process of ageing (Bozalongo et al., 2007). The decrease in catechin content at the end of the ageing period of the present study can be explained by the condensation of these compounds with some other compounds. The increase in gallic acid contents can be explained by gallic acid formation through hydrolysis of hydrolysable tannins. Vanillic acid is especially specific to oak trees and it passes to final product during the ageing of wines and vinegars in toasted oak barrels or ageing with the supplementation of oak chips. Similar to results, Cerezo et al. (2008) determined a decrease in amount of (+)-catechin and an increase in the amount of gallic acid and vanillic acid during the acetification of red wine vinegars oak barrels. Lignin constitutes about 20-25\% of oak barrels. Vanillic acid, syringaldehyde-like benzoic-type aldehydes and confiraldehyde and sinapaldehydes-like cinnamic aldehydes formed through lignin degradation during the oak chips-supplemented ageing of liquid foods pass to the final product and play a great role in sensory characteristics of the final products.

Tesfaye et al. (2004) in a study, supplemented Sherry wine vinegars with $2 \%(\mathrm{~g} / \mathrm{mL})$ boiled and toasted mid-size oak chips and aged the resultant vinegars for 90 days. Researchers indicated rapid increases in individual phenolics (gallic acid and vanillic acid) during the initial 15 days of ageing. An increase was observed in quantities of the other phenolics throughout the rest of the ageing period. Researchers indicated that 15 days were sufficient during the ageing of Sherry wine vinegars to achieve desired phenolic levels in vinegars.

Cerezo et al. (2009) tried to identify how different wood barrels used in ageing influenced vinegar quality. Researchers aged red wine and balsamic vinegars in locust, cherry, chestnut and oak barrels and reported significant increases in 2-furfuraldehyde, protocatecaldehyde and vanillic acid concentrations of vinegars aged in oak barrels. Present findings comply with the results of Tesfaye et al. (2004) and Cerezo et al. (2009).

Cerezo et al. (2014) indicated that wood chips were commonly used to shorten the ageing duration of vinegars. It was observed in the present study that 15 days were sufficient to achieve the greatest pass/extraction of polyphenols into the vinegar. 


\section{Aroma Compounds of Vinegar Samples}

Aroma compounds of the vinegar samples are provided in Table 5. In UC samples, 1-hydroxy- 2-propanon (20.94\%); 3-hydroxy-2-butanone (16.22\%), 1,3propandiol (14.46\%) and 1,2,3-propantriol (18.2\%) had the greatest quantities in the $0^{\text {th }}$ month.

In UC vinegar samples, 9-octadecanoic acid methyl ester (31.06\%), 2,3-butandiol (18.13\%) and hexadecanoic acid methyl ester $(16.94 \%)$ had the greatest quantities at the end of the $3^{\text {rd }}$ month. In OCS samples, 9-octadecanoic acid methyl ester (40.85\%), hexadecanoic acid methyl ester $(22.13 \%)$ and 2-nitro ethanol (13.35\%) had the greatest quantities at the end of the $3^{\text {rd }}$ month.

When the UC and OCS vinegar samples were compared at the end of the $3^{\text {rd }}$ month, it was observed that OCS samples had greater quantities of 3-hydroxy-2-butanone, hexadecanoic acid methyl ester, 9,12-octadecanoic acid methyl ester and 9-octadecanoic acid methyl ester. UC vinegar samples had greater quantities of 2,3-butanediol, 1,3-propandiol; nonanal, 1,2-benzendicarboxylic acid diethyl ester than OCS vinegar samples.

In UC vinegar samples, while 1-hydroxy-2-propanon content was measured as $20.94 \%$, 3-propandiol content was measured as $14.46 \%$ and 1,2,3-proponitrol content was measured as $12.21 \%$ in the $0^{\text {th }}$ month, these compounds were not encountered in UC vinegar samples at the end of the $3^{\text {rd }}$ month.

At the end of the $3^{\text {rd }}$ month, 9-octadecanoic acid methyl ester had the greatest quantity $(31.06 \%)$ in UC vinegar samples and it was followed by hexadecanoic acid methyl ester $(16.94 \%)$. These compounds were not encountered in $\mathrm{UC}$ vinegar samples in the $0^{\text {th }}$ month.
At the end of the $3^{\text {rd }}$ month, 2,3-butanol content was measured as $18.13 \%$ in UC vinegar samples and as $3.42 \%$ in OCS vinegar samples; hexadecanoic acid methyl ester ratio was measured as $16.94 \%$ in UC vinegar samples and as $22.13 \%$ in OCS vinegar samples; 9-octadecanoic acid methyl ester ratio was measured as $31.06 \%$ in UC vinegar samples and as $40.85 \%$ in OCS vinegar samples. While 2nitro ethanol was not encountered in UC vinegar samples, the OCS vinegar samples had a value of $13.35 \%$ at the end of the $3^{\text {rd }}$ month.

Ünal (2007) indicated that methods of production had significant effects on sensory characteristics and the chemical composition of the vinegars. It was also reported that slow methods yielded greater acid contents (5.79-6.59 $\mathrm{g} / 100 \mathrm{ml}$ ) than deep culture methods and slow methods were also richer in aroma compounds (methyl acetate, acetaldehyde, methyl alcohol, 2-methyl-1-propanol, 1propanol, 3-methyl-1-butanol, 2-methyl-1-butanol, 2 phenylethanol) (Akbaş, 2008).

Charles et al. (2000) determined aroma compounds of red wine vinegars with different acidity ratios through GC. Researchers divided primary aroma compounds of red wine vinegars into two groups including 2-3-methyl-1butanol, 2-hydroxy-3-butanon, acetic acid, 3-methyl butanoic acid and 2-phenyl ethanol. Researchers also identified new compounds mostly in ester forms (2,3butandiol monoacetate, 1,2,3-propantriol monoacetate, 1,2,3-propantriol diacetate) and ketones (3hydroxy-2-pentanon, 2-hydroxy-3-pentanon and 3 acetoxy-2-butanon, 3-acetoxy-3-butanon) which were not previously encountered in wine vinegars (Akbaş, 2008).

Table 5. Aroma compounds of the vinegar samples

\begin{tabular}{|c|c|c|c|c|c|}
\hline \multicolumn{2}{|l|}{$0^{\text {th }}$ month } & \multicolumn{4}{|c|}{$3^{\text {rd }}$ month } \\
\hline $\mathrm{UC}$ & $(\%)$ & $\mathrm{UC}$ & $(\%)$ & $\mathrm{OCS}$ & $(\%)$ \\
\hline 3-hydroxy-2-butanon & 16.22 & 3-hydroxy-2-butanon & 5.12 & 3-hydroxy-2-butanon & 5.12 \\
\hline 2,3-butandiol & 12.02 & 2,3-butandiol & 18.13 & 2,3-butandiol & 3.42 \\
\hline 1,3-propandiol & 14.46 & 1,3-propandiol & 3.32 & 1,3-propandiol & 2.34 \\
\hline $\begin{array}{l}\text { hexadecanoic acid methyl ester } \\
\text { (Palmitic acid methyl ester) }\end{array}$ & 2.05 & $\begin{array}{l}\text { hexadecanoic acid methyl } \\
\text { ester }\end{array}$ & 16.94 & $\begin{array}{l}\text { hexadecanoic acid methyl } \\
\text { ester }\end{array}$ & 22.13 \\
\hline 9-octadecanoic acid methyl ester & 1.56 & $\begin{array}{l}\text { 9-octadecanoic acid } \\
\text { methyl ester }\end{array}$ & 31.06 & $\begin{array}{l}\text { 9-octadecanoic acid } \\
\text { methyl ester }\end{array}$ & 40.85 \\
\hline Naphthalene & 0.53 & & & Naphthalene & 0.49 \\
\hline Methyl stearate & 0.95 & Methyl stearate & 2 & & \\
\hline Dianhydromannitol & 5,28 & Nonanal & 0.58 & Nonanal & 0.11 \\
\hline 1-hydroxy-2-propanon & 20.94 & $\begin{array}{l}\text { 9,12-octadecadienoic acid } \\
\text { methyl ester }\end{array}$ & 1.79 & $\begin{array}{l}\text { 9,12-octadecadienoic acid } \\
\text { methyl ester }\end{array}$ & 2.14 \\
\hline Acetic acid & 4.13 & $\begin{array}{l}\text { 1,2-benzendicarboxylic } \\
\text { acid diethyl ester }\end{array}$ & 16.18 & $\begin{array}{l}\text { 1,2-benzendicarboxylic } \\
\text { acid diethyl ester }\end{array}$ & 0.35 \\
\hline 1-dodesen & 0.29 & Phenylyethyl alcohol & 0.36 & Phenylethyl alcohol & 0.58 \\
\hline 1-nonadesen & 0.47 & Azulene & 0.75 & 1,3-butandiol & 2.41 \\
\hline & & 2-dodecenal & 0.38 & 2-nitro-ethanol & 13.35 \\
\hline 1,2,3-propantriol & 18.2 & $\begin{array}{l}\text { nonanoic acid, 9- } \\
\text { oxymethyl ester }\end{array}$ & 0.47 & 2-hydroxy propionic acid & 4.99 \\
\hline 1-pentadesen & 0.57 & diethyl phthalate & 1.51 & $\begin{array}{l}\text { 11-octadecenoic acid } \\
\text { methyl ester }\end{array}$ & 1.28 \\
\hline $\begin{array}{l}\text { 2-hydroxy-3-methyl-2- } \\
\text { cyclopentene, }\end{array}$ & 1.83 & $\begin{array}{l}\text { 10-octadecanoic acid } \\
\text { methyl ester }\end{array}$ & 1.41 & 2-undesenal, e- & 0.15 \\
\hline Benzenethanol & 0.26 & $\begin{array}{l}\text { 1,2-benzendicarboxylic } \\
\text { acid diethyl ester }\end{array}$ & 4.07 & $\begin{array}{l}\text { nonanoik acid, 9- } \\
\text { oxymethyl ester }\end{array}$ & 0.29 \\
\hline 1,2-propandiol & 0.24 & & & & \\
\hline
\end{tabular}


Marin et al. (2002) investigated aroma compounds of vinegars aged and non-aged in wood barrels with the HSSPME (head space solid phase micro extraction) method and indicated this method as a fast and easy method. Researchers reported the primary aroma compounds of the vinegars as 2-methyl-1-propanol, 2,3-methyl-1-butanol, 3hydroxy-2-butanon, 2,3-butandiol and isopentanoic acid. Ageing in wood barrels increased 3-hydroxy-2-butanonlike aroma compound concentrations (Akbaş, 2008).

Del Signore (2001) conducted a research on aroma compounds of traditional balsamic vinegars produced in Modena region and reported acetaldehyde concentrations as between $0.44-104.59 \mathrm{mg} / \mathrm{L}, 1$-propanol concentrations as between $0.03-8.0 \mathrm{mg} / \mathrm{L}$ and 2-methyl-1-butanol concentrations as between 0.07-14.47 mg/L (Akbaş, 2008).

\section{Conclusion}

It was observed in the present study that oak chipssupplementation increased total phenolics and some individual phenolics of grape vinegar samples. Increasing gallic acid and vanillic acid quantities indicated extraction of phenolic compounds of oak chips into the vinegar. A prolonged ageing period from 1 month to 3 months increased the quantity of some individual phenolics (gallic acid, vanillic acid), but did not yield significant changes in total phenolics. At the end of the ageing period, increases were observed in 3-hydroxy-2-butanon, hexadecanoic acid methyl ester, 9-12-octadecadienoic acid methyl ester, 9octadecanoic acid methyl ester concentrations of OCS vinegar samples. Extraction of phenolics into vinegars largely depends on chip size, botanical and geographical origin of oak trees, type of toasting, dosage and application durations. Oak chips did not have any significant effects on color parameters $\left(L^{*}, a^{*}, b^{*}\right)$ of vinegar samples. Today, consumers mostly tend to organoleptic and sensory foodstuffs different from traditional ones. Consumers are also more conscious about quality foods and drinks with positive impacts on their health. It was concluded based on present findings that extraction of oak phenolics into vinegar improved vinegar quality. As an alternative to traditional oak barrel-ageing, the use of oak chips may shorten process durations, reduce production costs, offer an easy method of ageing to producers. With these advantages, oak chips will improve the competitive power of the producers and allow consumers to reach healthier products at cheaper rates.

\section{Acknowledgement}

This study was supported by Tokat Gaziosmanpaşa University Scientific Research Projects (TGOÜ-BAP) Unit with project No: 2017/109. We would like to thank TGOÜBAP for their contributions.

\section{References}

Adams MR. 1998. Vinegar. In: Wood BJB (Editor) Microbiology of Fermented Foods, Blackie Academic and Professional, London, UK.

Akbaş M. 2008. A research on the determination of composition of grape vinegars produced in Turkey and their conformity to food legislation. MSc. thesis, University of Çukurova, Adana, Turkey.
Aktan N, Yıldırım HK. 2011. Sirke Teknolojisi. Ege University Printing House, İzmir, Turkey.

Angioni A, Pintore GA, Caboni P. 2012. Determination of wine aroma compounds by dehydration followed by GC/MS. Journal of AOAC International, 95: 813-819.

Anlı RE. 1999. Meşe fiçıların özellikleri ve şarabın yıllanmasındaki önemleri. Gida, 24: 379-383.

Anonymous 2003. TSE-Sirke-Tarım Kökenli Sıvılardan Elde Edilen Ürün-Tarifler, Özellikler ve işaretleme, TS 1880 EN 13188, Türk Standartları Enstitüsü, Ankara.

Bakir S, Devecioğlu D, Kayacan S, Toydemir G, KarbancioğluGuler F, Çapanoğlu E. 2017. Investigating the antioxidant and antimicrobial activities of different vinegars. European Food Research and Technology, 243: 2083-2094.

Bayram M, Kaya C, Esin-Yücel E, Gülmez E, Terzioğlu E. 2018. Pirinç sirkesi ve çeşitli ticari sirkelerin bazı kalite özellikleri. Akademik Gida, 16: 293-300.

Bouaziz M, Sayadi S. 2005. Isolation and evaluation of antioxidants from leaves of a Tunisian cultivar olive tree. European Journal Lipid Science and Technology, 107: 497504.

Bozalongo R, Carrillo JD, Torroba MÁF, Tena MT. 2007. Analysis of French and American oak chips with different toasting degrees by headspace solid-phase microextractiongas chromatography-mass spectrometry. Journal of Chromatography A, 1173: 10-17.

Cano-López M, Pardo-Minguez F, López-Roca JM, GómezPlaza E. 2007. Chromatic characteristics and anthocyanin profile of a micro-oxygenated red wine after oak or bottle maturation. European Food Research and Technology, 225: 127-132.

Casale M, Abajo MJS, Sáiz JMG, Pizarro C, Forina M. 2006. Study of the aging and oxidation processes of vinegar samples from different origins during storage by near-infrared spectroscopy. Analytica Chimica Acta, 557: 360-366.

Cemeroğlu B, Yemenicioğlu A, Özkan M. 2004. Meyve ve sebzelerin bileşimi. In: Cemeroğlu B (editor). Meyve Sebze İşleme Teknolojisi 2, Başkent Printing, Ankara, Turkey.

Cerezo AB, Tesfaye W, Torija MJ, Mateo E, Parrilla MCG, Troncoso AM. 2008. The phenolic composition of red wine vinegar produced in barrels made from different woods. Food Chemistry, 109: 606-615.

Cerezo AB, Espartero JL, Winterhalter P, Garcia-Parrilla MC, Troncoso AM. 2009. (+)-Dihydrorobinetin: a marker of vinegar aging in acacia (Robinia pseudoacacia) wood. $\mathrm{J}$ Journal of Agricultural and Food Chemistry, 57: 9551-9554.

Cerezo AB, Álvarez-Fernández MA, Hornedo-Ortega R, Troncoso AM, García-Parrilla MC. 2014. Phenolic composition of vinegars over an accelerated aging process using different wood species (acacia, cherry, chestnut, and oak): effect of wood toasting. Journal of Agricultural and Food Chemistry, 62: 4369-4376.

Charles M, Martin B, Ginies C, Etievant P, Coste G, Guichard E. 2000. Potent aroma compounds of two red wine vinegars. Journal of Agricultural and Food Chemistry, 48: 70-77.

Croft KD. 1998. The chemistry and biological effects of flavonoids and phenolic acids. Annals of the New York Academy Sciences, 854: 435-442.

Del Signore A. 2001. Chemometric analysis and volatile compounds of traditional balsamic vinegars from Modena. Journal of Food Engineering, 50: 77-90.

Fujieda M, Tanaka T, Suwa Y, Koshimizu S, Kouno I. 2008. Isolation and structure of whiskey polyphenols produced by oxidation of oak wood ellagitannins. Journal of Agricultural Food Chemistry, 56: 7305-7310.

Gómez-Plaza E, Gil-Munoz R, López-Roca JM, MartínezCutillas A, Fernández-Fernández JI. 2002. Maintenance of colour composition of a red wine during storage. Influence of prefermentative practices, maceration time and storage. LWT-Food Science and Technology, 35: 46-53. 
Guerrero ED, Mejías RC, Marín RN, Bejarano MJR, Dodero MCR, Barroso CG. 2011. Accelerated aging of a Sherry wine vinegar on an industrial scale employing microoxygenation and oak chips. European Food Research and Technology, 232: $241-254$.

Hassen I, Casabianca H, Hosni K. 2015. Biological activities of the natural antioxidant oleuropein: Exceeding the expectation-A mini-review. Journal of Functional Foods, 18 : 926-940.

He F, Pan QH, Shi Y, Duan CQ. 2008. Chemical synthesis of proanthocyanidins in vitro and their reactions in aging wines. Molecules, 13: 3007-3032

Marin RN, Mejías RC, Moreno MDVG, Rowe FG, Barroso CG. 2002. Headspace solid-phase microextraction analysis of aroma compounds in vinegar: Validation study. Journal of Chromatography A, 967: 261-267.

Martin JFG, Sun DW. 2013. Ultrasound and electric fields as novel techniques for assisting the wine ageing process: The state-of-the-art research. Trends in Food Science and Technology, 33: 40-53.

OIV 2018. Compendium of methods of analysis of wine vinegars. Available at: http://www.oiv.int/en/technical-standards-anddocuments/methods-of analysis/compendium-of-methodsof-analysis-of-wine-vinegars (accessed 20 October 2017).

Ozturk I, Caliskan O, Tornuk F, Ozcan N, Yalcin H, Baslar M, Sagdic O. 2015. Antioxidant, antimicrobial, mineral, volatile, physicochemical and microbiological characteristics of traditional home-made Turkish vinegars. LWT-Food Science and Technology, 63: 144-151.

Plessi M. 2003. Vinegar. In: Caballero B, Trugo LC, Finglas PM (editors). Encyclopedia of Food Sciences and Nutrition, Academic Press, Oxford.

Prida A, Puech JL. 2006. Influence of geographical origin and botanical species on the content of extractives in American, French, and East European oak woods. Journal of Agricultural Food Chemistry, 54: 8115-8126.
Re R, Pellegrini N, Proteggente A, Pannala A, Yang M, RiceEvans C. 1999. Antioxidant activity applying an improved ABTS radical cation decolorization assay. Free Radical Biology and Medicine, 26: 1231-1237.

Sáiz-Abajo MJ, González-Sáiz JM, Pizarro C. 2005. Multiobjective optimisation strategy based on desirability functions used for chromatographic separation and quantification of 1-proline and organic acids in vinegar. Analytica Chimica Acta, 528: 63-76.

Sáiz-Abajo MJ, González-Sáiz JM, Pizarro C. 2006. Prediction of organic acids and other quality parameters of wine vinegar by near-infrared spectroscopy. A feasibility studies. Food Chemistry, 99: 615-621.

Sengun IY, Kilic G, Ozturk B. 2019. Screening physicochemical, microbiological and bioactive properties of fruit vinegars produced from various raw materials. Food Science and Biotechnology, 29: 401-408.

Singh DP, Verma S, Prabha R. 2018. Investigations on Antioxidant Potential of Phenolic Acids and Flavonoids:The Common Phytochemical Ingredients in Plants. Journal of Plant Biochemistry and Physiology, 6.

Singleton VL, Rossi JA. 1965. Colorimetry of total phenolics with phosphomolybdic-phosphotungstic acid reagents. American Journal of Enology Viticulture, 16: 144-158.

Tesfaye W, Morales ML, Benitez B, Garcia-Parrilla MC, Troncoso AM. 2004. Evolution of wine vinegar composition during accelerated aging with oak chips. Analytica Chimica Acta, 513: 239-245.

Ünal E. 2007. A study on vinegar production from Dimrit grape by different methods. Msc. thesis, University of Çukurova, Adana, Turkey.

Yang CS, Landau JM, Huang MT, Newmark HL. 2001. Inhibition of carcinogenesis by dietary polyphenolic compounds. Annual Review Nutrition, 21: 381-406.

Zhang B, Cai J, Duan CQ, Reeves M, He F. 2015. A review of polyphenolics in oak woods. International Journal of Molecular Sciences, 16: 6978-7014. 